Author version: Bot. Mar., vol. 54(1); 2011; 3-11

\title{
Increasing evidence for the important role of Labyrinthulomycetes in marine ecosystems
}

\section{Seshagiri Raghukumar* ${ }^{1}$ and Varada S. Damare ${ }^{2}$}

${ }^{1}$ Myko Tech Pvt. Ltd., 313, Vainguinnim Valley, Dona Paula, Goa 403004, India. e-mail: s_raghukumar@mykotech.com

${ }^{2}$ National Institute of Oceanography, Dona Paula, Goa 403004, India

* Corresponding author

Running Title: Role of Labyrinthulomycetes in marine ecosystems

\begin{abstract}
This review summarizes increasing evidence for the role of Labyrithulomycetes in marine ecosystems gathered over the last six decades. It focuses on their diversity, habitats, biomass, productivity and overall role in food webs and remineralization. Earlier studies contributed enormously to the cultured diversity of Labyrinthulomycetes. In recent years, their uncultured diversity has been demonstrated in exotic environments like the deep sea and anoxic waters. These findings emphasize the need for novel culture methods to grow these organisms. Many species seem to be substrate-specific in their occurrence. Their commensalistic or mutualistic occurrence in marine invertebrates deserves attention. The biomass of Labyrinthulomycetes in the water column may often match or even exceed that of bacteria, although such occurrences seem to be seasonal. There is a major knowledge gap on their productivity and turnover in the water column. The high biomass and production of several degradative enzymes indicate their importance as remineralizers in the ocean. However, the mechanisms by which they overcome bacterial competition are not clear. It is likely that they occupy special niches, such as marine aggregates. One role of the Labyrinthulomycetes suggested in this review, based on preliminary experiments, is that of 'left-over scavenging', following bacterial growth.
\end{abstract}

Key words: Labyrinthulomycetes, ecology, diversity, remineralizers, scavengers 


\section{Introduction}

Thraustochytrids elicited much excitement in the initial years after their discovery in 1936 (Sparrow 1936) as a unique group of obligately marine, biflagellate, unicellular fungi. More recently, it has become clear that they are much more than mycological curiosities. Their importance in biotechnology, particularly in the production of the omega-3 polyunsaturated fatty acid (PUFA), docosahexaenoic acid (DHA) is now well established (Fan et al. 2000, Raghukumar 2008). Research in the last two decades has also provided increasing evidence for their importance in marine ecological processes (Raghukumar 2002) warranting a review on what we know and what we ought to know regarding their role in the sea. Indeed, a discussion on thraustochytrids necessarily extends beyond this particular group to include related labyrinthulids and aplanochytrids, all of which are marine and constitute the Labyrinthulomycetes (see Porter 1990, Leander and Porter 2001) of the Kingdom Straminipila (Dick 2001), or the Phylum Heterokonta of the Kingdom Chromista (Cavalier-Smith et al. 1994).

Briefly, all three groups produce heterokont, biflagellate zoospores and are also characterized by the ectoplasmic net elements (EN), extensions of plasma membrane that are associated with a sagenogenetosome organelle at the point of their origin in the cell. The labyrinthulids comprise a single genus Labyrinthula Cienk.; the members of this genus are colonial (Pokorny 1967). The aplanochytrids are unicellular or colonial and reproduce mostly using a gliding movement involving the EN (Leander and Porter 2001). Thraustochytrids differ in being unicellular and reproducing solely by means of biflagellate zoospores.

Four fundamental questions are important in providing clues about the ecological role of Labyrinthulomycetes, as with any other group of organisms:

1. Which species inhabit a given ecosystem?

2. In which specific habitats do they occur?

3. How many of them exist in each habitat and what are their biomasses and productivities?

4. What is their exact role in food web linkages and with which other organisms do they compete?

Eminent mycologists during the early years of research on Labyrinthulomycetes contributed substantially towards their ecology. The period between late 1930s and 1960s saw F.K. Sparrow, H. Vishniac and S. Goldstein contributing towards the taxonomy and biodiversity of thraustochytrids, and 
their physiological adaptations and requirements. A. Gaertner and A. Ulken unequivocally showed the occurrence of thraustochytrids in estuarine and coastal waters, during the 1960 s and $70 \mathrm{~s}$. At the same time, E.B.G. Jones, S.T. Moss, D. Porter and F.O. Perkins studied the occurrence of thraustochytrids in various habitats and also their ultrastructure (see Bremer 1976, Jones and Harrison, 1976, Moss 1986). The exhaustive work on carbon and nitrogen nutrition of thraustochytrids by G. Bahnweg (Bahnweg $1979 \mathrm{a}, \mathrm{b})$ is still a useful reference to their physiology. By the 1980s, certain salient features of the ecology of Labyrinthulomycetes had become clear. First of all, culturing of Labyrinthulomycetes had become a routine and standard procedure to isolate them. Baiting with pine pollen or Artemia larvae and plating on nutrient rich media were the standard methods (Porter 1990). This demonstrated that thraustochytrids were ubiquitous in occurrence, present in practically every possible habitat in the sea (see Raghukumar 2002). Some of the most common habitats are decaying mangrove leaves, decomposing algae and faecal pellets of marine invertebrates. Studies on the ecology of these organisms progressed rapidly since the 1990s. This review focuses on the four questions above to understand the ecology of Labyrinthulomycetes.

\section{Diversity of Labyrinthulomycetes}

Unraveling taxonomic diversity in different habitats is a major step towards determining the physiological and biochemical characteristics of individual species and contributes to understanding their ecology. Routine culture methods practiced by all researchers of this group since the discovery of thraustochytrids, have now resulted in a fairly comprehensive picture of diversity. The labyrinthulids and the aplanochytrids are represented by a single genus, Labyrinthula Cienk. and Aplanochytrium Bahnweg et Sparrow, respectively (Table 1). The thraustochytrids comprise 5 genera with about 30 species (Dick 2001). These taxonomic delineations were made solely by morphology and life cycle. Yokoyama and Honda (2007) and Yokoyama et al. (2007) in recent years, have split Schizochytrium S. Goldst. et Belsky and Ulkenia A. Gaertn. into 3 and 4 genera, respectively, based on 18S rDNA phylogeny, carotenoid profile and fatty acid composition (Table 1). A major knowledge gap in the ecology of Labyrinthulomycetes is detailed information on the physiology and biochemistry of individual species. H. Vishniac and S. Goldstein (see Goldstein 1973) made significant contributions in the early years towards this aspect. Such studies on individual species need to be revived. 
It is likely that cultured diversity represent only a small fraction of the actual diversity of Labyrinthulomycetes. A comparison of cultured numbers of thraustochytrids with actual cell counts in the Arabian Sea indicated that numbers obtained by the culturing method were $10^{3}$ times lower than those obtained by the AfDD (epifluorescence direct detection) technique (Raghukumar et al. 2001). Indeed, there has been increasing evidence to show the presence of uncultured Labyrinthulomycetes (Table 2). Such evidence has been emerging from locations such as the aphotic zone in the Antarctic polar front (Lopez-Garcia et al. 2001) and anoxic environments of Cariaco Basin and Berkeley Aquatic Park (Dawson and Pace 2002, Stoeck et al. 2003), where completely new phylogenetic lineages belonging to stramenopiles were discovered. One such lineage retrieved from a depth of $2000 \mathrm{~m}$ in Antarctica was found to be at the phylogenetic base of the Labyrinthulomycetes (Lopez-Garcia et al. 2001). This lineage was termed MAST-5, a cluster representing deep sea protists, with no sequences from surface waters being affiliated with it (Massana et al. 2004). The existence of this cluster has changed the earlier belief that traditionally dark, cold, oligotrophic, low-biomass deep-sea waters are inhospitable. During a study on the diversity of photosynthetic and non-photosynthetic picoeukaryotes in coastal and open ocean waters, two sequences of thraustochytrids from a total of 26 stramenopile sequences were detected in the English Channel off Roscoff (Vaulot et al. 2002). A clone, NOR50.59, close to the thraustochytrids was found in a sample from the western edge of a Greenland, Norwegian and Barents Sea transect (Lovejoy et al. 2006). A clone closest to Oblongichytrium multirudimentale (S. Goldst.) R. Yokoy. et D. Honda (as Thraustochytrium multirudimentale S. Goldst.) was recovered at 270 and $340 \mathrm{~m}$ depth from the anoxic Cariaco Basin (Stoeck et al., 2003). Another clone close to Aplanochytrium minuta (S. W. Watson et Raper) C. A. Leander et D. Porter was recovered from an anoxic environment in Berkeley Aquatic Park (Dawson and Pace 2002). Thus, novel lineages belonging to this group of organisms appear to be present even in exotic environments. Even easily accessible coastal environments may hold uncultured and novel Labyrinthulomycetes. Thus, a cultivationindependent method using a Labyrinthulomycete specific primer yielded 68 nearly full length 18S rDNA amplicons from 4 sediment and 3 seawater samples collected in estuarine habitats of Long Island, New York, most of which appeared to be new, undescribed Labyrinthulomycete members (ColladoMercado et al. 2010). There is a dire need for alternate culture methods for isolating hitherto uncultured Labyrinthulomycetes using various nutrient sources, growth promoters and varying environmental conditions, such as temperature, light and oxygen levels. This opens up new avenues for future research on these organisms in anoxic environments. 


\section{The habitat: Unravelling substrate-species relationships}

One important finding on the ecology of Labyrinthulomycetes that has emerged is the substrate-specific relationship of various species. The best example, perhaps, is that of the genus Labyrinthula Cienk., which is associated with various seagrasses and fallen mangrove leaves. This genus was originally described from the seagrass Zostera by Cienkowski (1867). Labyrinthula species have been found to be the causal agent of the wasting disease of eelgrass Zostera sp. (Young 1943, Muehlstein et al. 1988). Their regular association with fallen mangrove leaves is also well known (Raghukumar et al. 1995, Yokochi et al. 2001). Labyrinthula Cienk. has also been found to parasitize species of the green alga Chaetomorpha Kuetzing and the cyanobacterium Lyngbya Agardh Ex Gomont (Raghukumar 1986, Raghukumar 1987). Although generally considered marine, a species of the genus has been found to parasitize terrestrial turf grass (Bigelow et al. 2005). To the best of our knowledge, Labyrinthula has not been described from coastal or offshore waters and sediments.

Raghukumar (1988) described Schizochytrium mangrovei Raghuk. from fallen mangrove leaves at Goa, India. This species has now been renamed Aurantiochytrium mangrovei (Raghuk.) R. Yokoy. et D. Honda. It has subsequently been isolated by numerous workers from the same habitat (Fan et al. 2002a). Fan et al. (2002b) have shown that zoospores of this species are chemotactically attracted to fallen leaves in mangrove waters. Yet another example of substrate-specific associations of Labyrinthulomycetes is that of species of Aplanochytrium Bahnweg et Sparrow with algae and seagrasses (Raghukumar 2002; Leander et al., 2004). Sathe-Pathak et al. (1993) found A. minuta (S. W. Watson et Raper) C. A. Leander et D. Porter to be regularly associated with the brown alga Sargassum cinereum J. Agardh. This species was isolated despite surface-sterilization of the fronds of the alga, suggesting an endobiotic habitat. The occurrence of Aplanochytrium species in algae is interesting, since many algae have high levels of antimicrobial phenolics.

One of the potential fields for exciting research is the association of Labyrinthulomycetes with marine invertebrates. Labyrinthulomycetes have frequently been found as parasites in a variety of invertebrates, particularly mollusks (Polglase 1980, Jones and O’Dor 1983, Bower 1987, Bower et al. 1989). Non-parasitic mutualistic and commensalistic relations are equally important. A number of thraustochytrids have been isolated from the guts of the sea urchin Lytechinus variegates (Lamarck) (Wagner-Merner et al. 1980). An immunofluorescence study on Ulkenia visurgensis (Ulken) A. Gaertn. 
showed that this thraustochytrid occurred regularly along the coelenteron of an obelian hydroid in tidal pools (see Raghukumar, 2002). Thraustochytrids were a nuisance while raising cell cultures of several invertebrates, including sponges and corals, suggesting that these organisms could be internal colonizers of the invertebrates (Rinkevich, 1999). Thraustochytrium pachydermum Erh. Scholz was found to be associated with cell cultures of the tunicate Botryllus schlosseri (Pallas) (Mo et al. 2002). A new thraustochytrid, designated FngI has been recently described from mucus of the scleractinian coral Favia sp. (Harel et al., 2008).

In a detailed study on the association between Labyrinthulomycetes and mesozooplankton in the central Indian Ocean, aplanochytrids were isolated from 171 of 2100 specimens (Damare and Raghukumar, 2010). A representative 14 of these were identified as Aplanochytrium kerguelense Bahnweg et Sparrow using conventional morphology and life cycles, and 8 using 18S rDNA sequences. Even more significantly, the authors developed ITS-based probes for isolates of this species and used these to detect the possible presence of this species within the tissues of chaetognaths.

The regular non-parasitic association of Labyrinthulomycetes with a variety of invertebrates raises the possibility of a strong relationship between the two, probably of a mutualistic nature. This seems even more possible in the association of Aplanochytrium kerguelense with oceanic mesozooplankton.

\section{Biomass and productivity of Labyrinthulomycetes}

Biomass levels may be considered as indirect measure of the success of an organism in a given ecological habitat. Microorganisms constitute the majority of living biomass in most planktonic ecosystems. Knowledge about the contribution of particular organisms to the organic carbon pool is essential in understanding trophic web functioning in a particular ecosystem. An MPN technique has been used to enumerate thraustochytrids in the waters of the North Sea (Gaertner and Raghukumar 1980, Raghukumar and Gaertner 1980). These studies yielded a clear picture of the seasonal and spatial pattern in population changes. However, culture studies are inadequate in providing a complete enumeration of the actual population. Following the development of the AfDD technique (Raghukumar and Schaumann 1993), several authors successfully enumerated these organisms in coastal and oceanic waters. The technique depends on the presence of sulphated polysaccharides in the cell walls of Labyrinthulomycetes. Although cells detected by this method have been generally considered as belonging to thraustochytrids, it would be better to assign them to the Labyrinthulomycetes, since the 
labyrinthulids and aplanochytrids also have sulphated polysaccharides in their cell walls. Aplanochytrids are particularly abundant in oceanic waters (Damare and Raghukumar 2008). Kimura et al. (1999) and Raghukumar et al. (2001) obtained a value of 20.6 pg C per thraustochytrid cell with an average cell diameter of $5 \mu \mathrm{m}$. These studies (Kimura et al. 1999, 2001, Raghukumar et al. 2001, Bongiorni et al. 2005a, Naganuma et al. 2006, Damare and Raghukumar 2008) have provided much insight into the biomass of these organisms. Thus, it is now clear that Labyrinthulomycetes often attain substantial numbers in the water column (Table 3) and their biomass as organic carbon is often considerable, occasionally even exceeding bacterial biomass (Fig. 1). In addition, Labyrinthulomycete biomass varies considerably both temporally and spatially, unlike the bacteria.

Standing biomass of microorganisms in the sea is the net result of production and grazing by microzooplankton. Biomass data, therefore, are only temporal snapshots and do not yield insight into dynamics. One of the present constraints in understanding the ecological role of thraustochytrids is the lack of a suitable technique to measure productivity in natural samples. In contrast to the thymidineincorporation method for bacteria (Fuhrman and Azam 1982) and the ergosterol synthesis rate technique for fungi (Newell 2001, Newell et al. 2000), no specific biochemical processes for estimating productivity of thraustochytrids has been found to date. Devising a technique to study productivity will tremendously help in understanding the dynamics of production and grazing that control the biomass of Labyrinthulomycetes in the marine environment.

\section{The role of Labyrinthulomycetes in the marine ecosystem}

Labyrinthulomycetes in the marine food web: The marine food web link of Labyrinthulomycetes is of tremendous interest because they synthesize omega-3 PUFA, DHA, a key essential fatty acid in the growth and maturation of crustaceans (Veloza et al. 2006). Synthesis rates of PUFAs by zooplankton are generally $<2 \%$ of their requirements. Hence zooplankton is believed to obtain DHA from their prey. The microbial loop comprises organisms within the pico- to nanoplankton size range. Labyrinthulomycetes, the cells of which range from 2 to $20 \mu \mathrm{m}$ fall within this range and hence are ideally sized to play a role in the 'microbial loop'. As is the case for bacteria, Labyrinthulomycetes may also convert DOM into living biomass that is subsequently ingested by heterotrophic flagellates and ciliates. These protists, in turn, would be fed upon by the mesozooplankton, (Naganuma et al. 2006). In addition to the requirement of PUFAs for planktonic organisms, these fatty acids are also essential for 
aquatic animals at higher trophic levels. The planktonic pool of dietary DHA for fish is highest in the mesozooplankton size fraction and thus the most efficient DHA transfer from planktonic food web to fish occurs through the mesozooplankton (Kainz et al. 2004). Several studies have attempted to trace the source of DHA in the food web (Veloza et al. 2006, Alonzo et al. 2005). Zooplankton incorporate fatty acids into their body from thraustochytrids they feed upon (Alonzo et al. 2005, Castilo et al. 2009). Hence, the involvement of Labyrinthulomycetes in the microbial loop may have far reaching implications in the food web (Naganuma et al. 1998, Kimura et al. 1999). However, few studies have examined the role of Labyrinthulomycetes as food for microzooplankton.

Labyrinthulomycetes as remineralizers in the ecosystem: By virtue of the production of various degradative enzymes and their absorptive mode of nutrition, the Labyrinthulomycetes may play an important role as remineralizers in the ocean. Bacteria are major remineralizers and decomposers, breaking down complex organic compounds to simpler ones. Labyrinthulomycetes in the water column may thrive on autochthonous and allochthonous plant material in coastal waters. Marine detritus appears to be an excellent substrate for the growth of Labyrinthulomycetes (Raghukumar et al. 1994, Sharma et al. 1994). Thraustochytrids are found in large numbers in mangrove detritus (Raghukumar et al. 1994). Bacteria and fungi present in the detritus produce several degradative enzymes that break down the complex organic constituents present in the detritus and mediate major biochemical changes therein. Microbially transformed detritus supports a variety of detritus-feeding animals that are important not only in ecosystem dynamics, but also in aquaculture (see Raghukumar et al. 1994, Sharma et al. 1994).

The role of Labyrinthulomycetes as remineralizers is bound to be affected by bacterial competition. Bacteria attain densities of at least $10^{6}$ cells $\mathrm{ml}^{-1}$ seawater, and are highly versatile in the production of extracellular, degradative enzymes. It is important to determine how Labyrinthulomycetes deal this competition in order to better understand their role as remineralizers.

An important question in this context is whether the Labyrinthulomycetes possess a special suite of enzymes that the bacteria do not. Thraustochytrids secrete a wide variety of extracellular enzymes in vitro, such as proteases, lipases, cellulases, amylases, xylanases, gelatinase, urease, phosphatase, chitinase and $\alpha-$ Glucosidase (Raghukumar et al. 1994, Sharma et al. 1994, Bremer and Talbot 1995, Bongiorni et al. 2005b, Damare and Raghukumar 2006, Taoka et al. 2009, Nagano et al. 2010). Members of the Labyrinthulomycetes generally seem to be inefficient in degrading chitin, which is a 
structural part of the exoskeleton of arthropod zooplankton (Jeuniaux and Voss-Foucart 1991). None of the Labyrinthulomycetes studied by Bahnweg (1979b) and Taoka et al. (2009) hydrolysed chitin. Likewise, none of the aplanochytrids from the zooplankton of oceanic waters produced chitinase, indicating that they may not significantly degrade zooplankton exoskeletons (Damare and Raghukumar, 2006). Members of Labyrinthulomycetes appear to be highly efficient in degrading protein. All 23 isolates studied by Bahnweg (1979b), 7 out of 11 isolates studied by Bongiorni et al. (2005b) and all aplanochytrids studied by Damare and Raghukumar (2006) produced protease. The production of protease as the sole extracellular degradative enzyme suggests that aplanochytrids might have an important role in the degradation of complex proteinaceous compounds of zooplankton cadavers. Bongiorni et al. (2005b) studied 19 different enzymes from thraustochytrids isolated from various substrates including sediments. Their study highlights the potential of thraustochytrids as diverse enzyme synthesizers, opening new perspectives on patterns of organic matter degradation processes in marine sediments. However, there is no evidence to date indicating that the Labyrinthulomycetes degrade special substrates unavailable to bacteria, and hence evidence of niche differentiation by substrate type. However, these are early days and the possibility cannot be ruled out yet. Wahid et al. (2008) demonstrated that species of Labyrinthula Cienk. and thraustochytrids lyse dead, gram negative bacterial cells by producing leucine aminopeptidase. This may be a specific role for these organisms. A variety of techniques has been used so far by different authors studying their enzymes, making it difficult to arrive at a comprehensive understanding. Furthermore, there are no studies on the specific activities and kinetics of the enzymes and their relation with biomass and life cycle stages. The importance of extracellular and cell-bound enzymes also needs to be considered in future. Such studies will throw light on the role of degradative enzyme production in the nutrition and survival strategies of Labyrinthulomycetes.

Transparent Extracellular Polysaccharides (TEPs) are a possible source of nutrition for Labyrinthulomycetes in the water column. Marine aggregates formed by coagulation of TEPs are regarded as hot spots of microbial activity. Bacterial activity in these aggregates may lead to remineralization of particulate organic matter, which is followed by.rapid successional changes in microbial populations in the aggregates. Thraustochytrids occur in patches in the water column (Damare and Raghukumar 2008, Naganuma et al. 2006), probably because of their colonization of marine aggregates (Lyons et al. 2005). 
During field and experimental studies on the relationship of TEPs and Labyrinthulomycetes, Damare and Raghukumar (2008) observed that the relationship between the two was variable, probably owing to the origin and chemistry of TEPs. Using lectins, they further found that thraustochytrids were generally positively related to TEPs concentrations that were relatively high in n-acetylneuraminic acid, a major component of bacterial EPS. Labyrinthulomycetes may prefer TEPs from bacterial origin over others, or they may colonize aggregates that have been already colonized and acted upon by bacteria, leaving behind refractory material inside the aggregate.

One useful approach to elucidating the role of Labyrinthulomycetes is the use of microcosms with defined substrates. Potential substrates include mangrove leaves (Fan et al. 2002a), decomposing algae (Sharma et al. 1994), faecal pellets (Raghukumar and Raghukumar 1999) and laboratory-generated aggregates (Damare et al., 2010). Such studies are likely much information on the role of these organisms.

\section{One possible role: Are Labyrinthulomycetes ‘left-over’ scavengers?}

It is common experience that when Labyrinthulomycetes are isolated using pine pollen or Artemia larvae, they grow on baits in the presence of bacteria. There are two possible explanations for this. (1) Labyrinthulomycetes and bacteria degrade different components of the baits. (2) Bacteria provide some essential nutrients to the Labyrinthulomycetes. In a simple experiment, we isolated thraustochytrids from seawater in the presence and absence of streptomycin and penicillin from two different habitats (Fig. 2). The percentage of isolation tubes with colonization of pine pollen was much higher in the initial few days when bacteria were suppressed using antibiotics. However, the number of thraustochytrids continued increasing with time even in the presence of bacteria. In one case, both treatments had an equal number of tubes colonized by thraustochytrids by day 11, by which time the bacteria had probably reached a stationary phase (Fig. 2a). In another experiment, cultures of three thraustochytrids were individually grown on pine pollen in natural seawater with bacteria and in antibiotic-amended seawater to suppress bacteria (Fig. 3). Percentage colonization of pine pollen was greater in tubes with antibiotics during the initial 2-3 days. However, $100 \%$ of pine pollen was colonized both in the presence and absence of bacteria by 3-5 days. These observations suggest the following: (1) bacteria compete with thraustochytrids for nutrients and the fungi grew faster in the absence of bacteria; (2) bacterially-colonized substrates still support good growth of thraustochytrids 
once bacterial growth stops and sufficient nutrients are present in such substrates to allow luxuriant growth of thraustochytrids. Thus, thraustochytrids might feed upon residual nutrients left over by bacteria, once bacterial growth on the substrates ceases.

As far as we know, aplanochytrids and thraustochytrids do not occupy a special spatial niche separately from bacteria (the labyrinthulids could be endobiontic, though). They do not seem to deter bacteria with antibacterial substances, nor do they appear to possess special enzymes not found in bacteria, although more studies are required on this. The productivity of Labyrinthulomycetes is not greater than that of bacteria; hence, the protists do not colonize substrates faster. Labyrinthulomycetes are capable of primary degradation of organic matter in the absence of bacteria. However, when faced with competition from bacteria, they may resort to 'left-over scavenging' of nutrient substrates following bacterial growth. One may ask: 'Are Labyrinthulomycetes the microbial hyenas of the sea?'

\section{Acknowledgements}

VD would like to thank the Director, NIO and Council of Scientific and Industrial Research (CSIR) for providing facilities to carry out Ph.D. work and Dr. Tapaswi, Librarian, NIO for providing several useful research articles. This is NIO's contribution number \#\#\#\#.

\section{References}

Alonzo, F., P. Virtue, S. Nicol and P. Nichols. 2005. Lipids as trophic markers in Antarctic krill.II. Lipid composition of the body and digestive gland of Euphausia superba in controlled conditions. Mar. Ecol. Progr. Ser. 296: 65-79.

Bahnweg, G. 1979a. Studies on the physiology of thraustochytriales I. Growth requirements and nitrogen nutrition of Thraustochytrium spp., Schizochytrium sp., Japonochytrium sp., Ulkenia spp. and Labyrinthuloides spp. Veröff. Inst. Meeresforsch. Bremerhaven 17: 245-268.

Bahnweg, G. 1979b. Studies on the physiology of thraustochytriales II. Carbon nutrition of Thraustochytrium spp., Schizochytrium sp., Japonochytrium sp., Ulkenia spp. and Labyrinthuloides spp. Veröff. Inst. Meeresforsch. Bremerhaven 17: 269-273.

Bigelow, D. M., M. W. Olsen and R. L. Gilbertson. 2005. Labyrinthula terrestris sp. nov., a new pathogen of turf grass. Mycologia 97: 185-190. 
Bongiorni, L., S. Mirto, A. Pusceddu and R. Danovaro. 2005a. Response of benthic protozoa and thraustochytrid protists to fish farm impact in seagrass (Posidonia oceanica) and soft-bottom sediments. Microb. Ecol. 50: 268-276.

Bongiorni, L., A. Pusceddu and R. Danovaro. 2005b Enzymatic activities of epiphytic and benthic thraustochytrids involved in organic matter degradation. Aquat. Microb. Ecol. 41: 299-305.

Bower, S. M. 1987. Labyrinthuloides haliotidis n.sp. (Protozoa: Labyrinthomorpha), a pathogenic parasite of small juvenile abalone in a British Columbia mariculture facility. Can. J. Zool. 65: 1996-2007.

Bower, S. M., N. McLean and D. J. Whitaker. 1989. Mechanism of infection by Labyrinthuloides haliotidis (Protozoa: Labyrinthomorpha), a parasite of abalone (Haliotis kamtschatkana) (Mollusca: Gastropoda). J. Invertebr. Pathol. 53: 401-409.

Bremer G.B. 1976. The ecology of lower marine fungi. In: (E.B. Gareth Jones, ed.). Recent advances in aquatic mycology. Elek Science, London. 313-333.

Bremer, G.B. and G. Talbot. 1995. Cellulolytic enzyme activity in the marine protist Schizochytrium aggregatum. Bot. Mar. 38: 37-41.

Castillo, C. E., R. S. Gapasin and Leaño E. M. 2009. Enrichment potential of HUFA-rich thraustochytrid Schizochytrium mangrovei for the rotifer Brachionus plicatilis. Aquaculture 293: 57-61.

Cavalier-Smith, T., M. T. E. P. Allsopp and E. E. Chao. 1994. Thraustochytrids are chromists, not Fungi: 18s rRNA signatures of Heterokonta. Phil. Trans. Royal Soc. London B 346: 387-397.

Cienkowski, L. 1867. Ueber den Bau und die Entwicklung der Labyrinthuleen. Max Schultze's Arch. Mikros. Anat. 3: 274-310.

Collado-Mercado, E., J. C. Radway and J. L. Collier. 2010. Novel uncultivated labyrinthulomycetes revealed by $18 \mathrm{~S}$ rDNA sequences from seawater and sediment samples. Aquat. Microb. Ecol. 58: 215-228.

Damare, V. and S. Raghukumar. 2006. Morphology and physiology of the marine straminipilan fungi, the aplanochytrids isolated from the equatorial Indian Ocean. Ind. J.Mar. Sci. 35: 326-340.

Damare, V. and S. Raghukumar. 2008. Abundance of thraustochytrids and bacteria in the equatorial Indian Ocean, in relation to Transparent Exopolymeric Particles (TEPs). FEMS Microbiol. Ecol. 65: 40-49.

Damare, V. and S. Raghukumar. 2010. Association of the stramenopilan protists, the aplanochytrids, with zooplankton of the equatorial Indian Ocean. Mar. Ecol. Prog. Ser. 399: 53-68. 
Damare V., S. Khalap and Seshagiri Raghukumar. 2010. Simple electric powered plankton wheel for the production of aggregates in seawater on-board ship. Ind. J.Mar. Sci. (In Press).

Dawson, S. C., and N. R. Pace. 2002. Novel kingdom-level eukaryotic diversity in anoxic environments. Proc. Natl. Acad. Sci. USA 99: 8324-8329.

Dick, M. W. 2001. Straminipilous fungi: Systematics of the peronosporomycetes including accounts of the marine straminipilous protists, the plasmodiophorids and similar organisms. Kluwer Academic Publishers, Dordrecht. pp. 670.

Fan, K.W., F. Chen, E.B.G. Jones and L.L.P. Vrijmoed. 2000. Utilization of food processing waste by thraustochytrids. Fungal Divers. 5: 185-194.

Fan, K. W., L. L. P. Vrijmoed and E. B. G. Jones. 2002a. Zoospore chemotaxis of mangrove thraustochytrids from Hong Kong. Mycologia 94: 569-578.

Fan, K.W., L. L. P. Vrijmoed and E. B. G. Jones. 2002b. Physiological studies of subtropical mangrove thraustochytrids. Bot. Mar. 45: 50-57.

Fuhrman, J. A. and F. Azam. 1982. Thymidine incorporation as a measure of heterotrophic bacterioplankton production in marine surface waters: evaluation and field results. Mar. Biol. 66: 109-120.

Gaertner, A. and S. Raghukumar. 1980. Ecology of thraustochytrids (lower marine fungi) in the Fladen Ground and other parts of the North Sea. I. "Meteor" Forschungsergebnisse A. 22: 165-185.

Goldstein, S. 1973. Zoosporic marine fungi (Thraustochytriaceae and Dermocystidiaceae). Annu. Rev. Microbiol. 27: 13-25.

Harel, M., E. Ben- Dov, D. Rasoulouniriana, N. Siboni, E. Kramarsky-Winter, Y. Loya, Z. Barak, Z. Wiesman and A. Kushmaro. 2008. A new thraustochytrid, strain Fng1, isolated from the surface mucus of the hermatypic coral Fungia granulose. FEMS Microbiol. Ecol. 64: 378-387.

Jeuniaux, C. and M. F. Voss- Foucart. 1991. Chitin biomass and production in the marine environment. Biochem. Syst. Ecol. 19: 347- 356.

Jones, E.B.G. and J.L. Harrison. 1976. Physiology of marine phycomycetes. In: (E.B. Gareth Jones, ed.). Recent advances in aquatic mycology. Elek Science, London, pp. 261-278.

Jones, G. M. and R. K. O’Dor. 1983. Ultrastructural observations on a thraustochytrid fungus parasitic in the gills of squid (Ilex illecebrosus LeSueur). J. Parasitol. 69: 903-911.

Kainz, M., M. T. Arts and A. Mazumder. 2004. Essential fatty acids in the planktonic food web and their ecological role for higher trophic levels. Limnol. Oceanogr. 49: 1784-1793. 
Kimura, H., M. Sato, C. Sugiyama and T. Naganuma. 2001. Coupling of thraustochytrids and POM, and of bacterio- and phytoplankton in a semi-enclosed coastal area: implication for different substrate preference by the planktonic decomposers. Aquat. Microb. Ecol. 25: 293-300.

Kimura, H., T. Fukuba and T. Naganuma. 1999. Biomass of thraustochytrid protoctists in coastal water. Mar. Ecol. Prog. Ser. 189: 27-33.

Leander, C. A. and D. Porter. 2001. The Labyrinthulomycota is comprised of three distinct lineages. Mycologia 93: 459-464.

Leander, C. L., D. Porter and B. S. Leander. 2004. Comparative morphology and molecular phylogeny of aplanochytrids (Labyrinthulomycota). Eur. J. Protist. 40: 317-328.

Lopez-García, P., F. Rodríguez-Valera, C. Pedro's-Alio' and D. Moreira. 2001. Unexpected diversity of small eukaryotes in deep-sea Antarctic plankton. Nature 409: 603-607.

Lovejoy, C., R. Massana and C. Pedro's-Alio'. 2006. Diversity and distribution of marine microbial eukaryotes in the Arctic Ocean and adjacent Seas. Appl. Environ. Microbiol. 72: 3085-3095.

Lyons, M. M., J. E. Ward, R. Smolowitz, K. R. Uhlinger and R. J. Gast. 2005. Lethal marine snow: Pathogen of bivalve mollusc concealed in marine aggregates. Limnol. Oceanogr. 50: 1983-1988.

Massana, R., J. Castresana, V. Balague', L. Guillou, K. Romari, A. Groisillier, K. Valentin and C. Pedro's-Alio'. 2004. Phylogenetic and ecological analysis of novel marine Stramenopiles. Appl. Environ. Microbiol. 70: 3528-3534.

Mo, C., J. Douek and B. Rinkevich. 2002. Development of a PCR strategy for thraustochytrid identification based on 18S rDNA sequence. Mar. Biol. 140: 883-889.

Morris, R. M., M. S. Rappé, S. A. Connon, K. L. Vergin, W. A. Siebold, C. A. Carlson and S. J. Giovannoni. 2002. SAR11 clade dominates ocean surface bacterioplankton communities. Nature 420: 806-810.

Moss, S.T. 1986. Biology and phylogeny of the Labyrinthulales and Thraustochytriales. In: (S.T. Moss, ed.) The biology of marine fungi. Cambridge University Press, Cambridge. pp. 105-129.

Muehlstein, L.K., D. Porter and F.T. Short. 1988. Labyrinthula sp., a marine slime mold producing the symptoms of wasting disease in eelgrass, Zostera marina. Marine Biology. 99: 465-472.

Naganuma, T., H. Kimura, R. Karimoto and V. Nikolay. 2006. Abundance of planktonic thraustochytrids and bacteria and the concentration of particulate ATP in the Greenland and Norwegian Seas. Pimenov Polar Biosci. 20: 37-45. 
Naganuma, T., H. Takasugi and H. Kimura. 1998. Abundance of thraustochytrids in coastal plankton. Mar. Ecol. Prog. Ser. 162: 105-110.

Nagano, N., S. Matsui, T. Kuramura, Y. Taoka, D. Honda and M. Hayashi. 2010. The distribution of extracellular cellulase activity in marine eukaryotes, thraustochytrids. Mar. Biotechnol. DOI 10.1007/s10126-010-9297-8.

Newell, S. Y. 2001. Multiyear patterns of fungal biomass dynamics and productivity within naturally decaying smooth cordgrass shoots. Limnol. Oceanogr. 46: 573-583.

Newell, S. Y., L. K. Blum, R. E. Crawford, T. Dai and M. Dionne. 2000. Autumnal biomass and potential productivity of salt marsh fungi from $29^{\circ}$ to $43^{\circ}$ north latitude along the United States Atlantic coast. Appl. Environ. Microbiol. 66: 180-185.

Pokorny, K.S. 1967. Labyrinthula. J. Protozool. 14: 697-708.

Polglase, J. L. 1980. A preliminary report on the thraustochytrid(s) and labyrinthulid(s) associated with a pathological condition in the lesser octopus Eledone cirrhosa. Bot. Mar. 23: 699-706.

Porter, D. 1990. Labyrinthulomycota. In: (L. Margulis, J. O. Corliss, M. Melkonian and D. Chapman eds) Handbook of Protoctista. Jones and Bartlett, Boston, MA. pp. 388-398.

Raghukumar, C. 1986. Thraustochytrid fungi associated with marine algae. Ind. J. Mar. Sci. 15: 121122.

Raghukumar, C. 1987. Fungal parasites of marine algae from Mandapam (South India). Dis. Aquat. Org. 3: $137-145$.

Raghukumar, S. 1988. Schizochytrium mangrovei sp. nov.: a thraustochytrid from mangroves in India. Trans. Brit. Mycol. Soc. 90: 627-631.

Raghukumar, S. 2002. Ecology of the marine protists, the Labyrinthulomycetes (Thraustochytrids and Labyrinthulids). Eur. J. Protistol. 38: 127-145.

Raghukumar, S. 2008. Thraustochytrid marine Protists: Production of PUFAs and other emerging technologies. Mar. Biotechnol. 10: 631-640.

Raghukumar, S. and A. Gaertner. 1980. Ecology of the thraustochytrids (lower marine fungi) in the Fladen Ground and other parts of the North Sea. II. Veröff. Inst. Meeresforsch. Bremerhaven 18: 289-308.

Raghukumar, S. and C. Raghukumar. 1999. Thraustochytrid fungoid protists in faecal pellets of the tunicate Pegea confoederata, their tolerance to deep-sea conditions and implication in degradation processes. Mar. Ecol. Prog. Ser. 190: 133-140. 
Raghukumar, S. and K. Schaumann. 1993. An epifluorescence microscopy method for direct detection and enumeration of the fungi-like marine Protists, the thraustochytrids. Limnol. Oceanogr. 38: $182-187$.

Raghukumar, S., S. Sharma, C. Raghukumar and V. Sathe-Pathak. 1994. Thraustochytrid and fungal component of marine detritus. IV. Laboratory studies on decomposition of leaves of the mangrove Rhizophora apiculata Blume. J. Exp. Mar. Biol. Ecol. 183: 113-131.

Raghukumar, S., N. Ramaiah and C. Raghukumar. 2001. Dynamics of thraustochytrid protists in the water column of the Arabian Sea. Aquat. Microb. Ecol. 24: 175-186.

Raghukumar, S., V. Sathe-Pathak, S. Sharma and C. Raghukumar. 1995. Thraustochytrid and fungal component of marine detritus. III. Field studies on decomposition of leaves of the mangrove Rhizophora apiculata Blume. Aquat. Microb. Ecol. 9: 117-125.

Rappé, M. S., S. A. Connon, K. L. Vergin and S. J. Giovannoni. 2002. Cultivation of the ubiquitous SAR11 marine bacterioplankton clade. Nature 418: 630-633.

Rinkevich B. 1999. Cell cultures from marine invertebrates: obstacles, new approaches and recent improvements. J. Biotechnol. 70: 133-153.

Sathe-Pathak, V., S. Raghukumar, C. Raghukumar and Sharma S. 1993. Thraustochytrid and fungal component of marine detritus. I. Field studies on decomposition of the brown alga Sargassum cinereum J. Ag. Indian J. Mar. Sci. 22: 159-167.

Sharma, S., C. Raghukumar, S. Raghukumar, V. Sathe-Pathak and D. Chandramohan. 1994. Thraustochytrid and fungal component of marine detritus II. Laboratory studies on decomposition of the brown alga Sargassum cinereum. J. Ag. J. Exp. Mar. Biol. Ecol. 175: 227242.

Sparrow, F. K. 1936. Biological observations on the marine fungi of Woods Hole waters. Biol. Bull. Mar. Biol. Lab., Woods Hole 70: 236-273.

Stoeck, T., and S. Epstein. 2003. Novel eukaryotic lineages inferred from small-subunit rRNA analyses of oxygen-depleted marine environments. Appl. Environ. Microbiol. 69: 2657-2663.

Taoka, Y., N. Nagano, Y. Okita, H. Izumida, S. Sugimoto and I. Hayashi. 2009. Extracellular enzymes produced by marine eukaryotes, thraustochytrids. Biosci. Biotechnol. Bioch. 73: 180-182.

Vaulot, D., K. Romari and F. Not. 2002. Are autotrophs less diverse than heterotrophs in marine picoplankton? TRENDS Microbiol. 10: 266-267. 
Veloza, A. J., F. E. Chu and K. W. Tang. 2006. Trophic modification of essential fatty acids by heterotrophic protists and its effects on the fatty acid composition of the copepod Acartia tonsa. Mar. Biol. 148: 779-788.

Wagner-Merner, B. T., W. R. Duncan and J. M. Lawrence. 1980. Preliminary comparison of Thraustochytriaceae in the guts of a regular and irregular echinoid. Bot. Mar. 23: 95-97.

Wahid, M. I., S. R. Bitoon, T. Fukunaga, T. Yoshikawa and T. Sakata. 2008. Comparative study of leucine aminopeptidases from marine labyrinthulid and thraustochytrid strains. Mem. Fac. Fish. Kagoshima Univ., Special Issue. 26-33.

Yokochi, T., T. Nakahara, T. Higashihara, M. Yamaoka and R. Kurane. 2001. A new isolation method for Labyrinthulids using a bacterium, Psychrobacter phenylpyruvicus. Mar. Biotechnol. 3: 68-73.

Yokoyama, R. and D. Honda. 2007. Taxonomic rearrangement of the genus Schizochytrium sensu lato based on morphology, chemotaxonomic characteristics, and 18S rRNA gene phylogeny (Thraustochytriaceae, Labyrinthulomycetes): emendation for Schizochytrium and erection of Aurantiochytrium and Oblongichytrium gen. nov. Mycoscience 48: 199-211.

Yokoyama, R., B. Salleh and D. Honda. 2007. Taxonomic rearrangement of the genus Ulkenia sensu lato based on morphology, chemotaxonomical characteristics, and 18S rRNA gene phylogeny (Thraustochytriaceae, Labyrinthulomycetes): emendation for Ulkenia and erection of Botryochytrium, Parietichytrium, and Sicyoidochytrium gen. nov. Mycoscience 48: 329-341.

Young, E. L. 1943. Studies on Labyrinthula, the etiologic agent of the wasting disease of eel-grass. Amer. J. Bot. 30: 586-593. 


\section{Legends to Figures}

Figure 1 Contribution of Labyrinthulomycetes to microbial carbon in different habitats in comparison with bacteria,.

Figure 2 Growth of thraustochytrids in isolation tubes using pine pollen baits and seawater without and with antibiotics to suppress bacteria. A total of 100 pollen were counted for each experiment to arrive at the percentage colonization. (a) Estuarine waters of Dona Paula, Goa; b) Mangrove waters of Chorao, Goa.

Figure 3 Colonization of pine pollen by three different isolates of thraustochytrids, 'SR', 'MAR03' and 'A6T', in seawater from Dona Paula, Goa, using natural seawater with bacteria and seawater with antibiotics to suppress bacteria. 
Table 1 A list of genera of Labyrinthulomycetes.

\begin{tabular}{|c|c|c|}
\hline $\begin{array}{c}\text { Higher Taxonomic } \\
\text { Groupings }\end{array}$ & $\begin{array}{c}\text { Present Circumscription } \\
\text { of genera }\end{array}$ & $\begin{array}{c}\text { Earlier circumscription of } \\
\text { genera }\end{array}$ \\
\hline Labyrinthulids & Labyrinthula Cienk. & Labyrinthula Cienk. \\
\hline Aplanochytrids & $\begin{array}{l}\text { Aplanochytrium Bahnweg } \\
\text { et Sparrow }\end{array}$ & $\begin{array}{l}\text { Aplanochytrium Bahnweg } \\
\text { et Sparrow }\end{array}$ \\
\hline \multirow[t]{10}{*}{ Thraustochytrids } & Thraustochytrium Sparrow & Thraustochytrium Sparrow \\
\hline & $\begin{array}{l}\text { Japonochytrium Kobayasi } \\
\text { et } \mathrm{M} \text {. Ôkubo }\end{array}$ & $\begin{array}{l}\text { Japonochytrium Kobayasi } \\
\text { et } \mathrm{M} \text {. Ôkubo }\end{array}$ \\
\hline & $\begin{array}{l}\text { Althornia E.B.G. Jones et } \\
\text { Alderman }\end{array}$ & $\begin{array}{l}\text { Althornia E.B.G. Jones et } \\
\text { Alderman }\end{array}$ \\
\hline & $\begin{array}{l}\text { Schizochytrium S. Goldst. et } \\
\text { Belsky emend. R. Yokoy. } \\
\text { et } \mathrm{D} \text {. Honda. }\end{array}$ & \multirow[t]{3}{*}{$\begin{array}{l}\text { Schizochytrium S. Goldst. et } \\
\text { Belsky }\end{array}$} \\
\hline & $\begin{array}{l}\text { Aurantiochytrium } \mathrm{R} . \\
\text { Yokoy. et } \mathrm{D} \text {. Honda }\end{array}$ & \\
\hline & $\begin{array}{l}\text { Oblongichytrium R. Yokoy. } \\
\text { et } \text { D. Honda }\end{array}$ & \\
\hline & $\begin{array}{l}\text { Ulkenia A. Gaertn. emend. } \\
\text { R. Yokoy., Salleh et D. } \\
\text { Honda }\end{array}$ & \multirow[t]{4}{*}{ Ulkenia A. Gaertn. } \\
\hline & $\begin{array}{l}\text { Botryochytrium R. Yokoy., } \\
\text { Salleh et D. Honda }\end{array}$ & \\
\hline & $\begin{array}{l}\text { Parietichytrium R. Yokoy., } \\
\text { Salleh et D. Honda }\end{array}$ & \\
\hline & $\begin{array}{l}\text { Sicyoidochytrium R. } \\
\text { Yokoy., Salleh et D. Honda }\end{array}$ & \\
\hline
\end{tabular}


Table 2 Some examples of the uncultured diversity in the Labyrinthulomycetes.

\begin{tabular}{|l|l|l|}
\hline \multicolumn{1}{|c|}{ Location } & \multicolumn{1}{|c|}{ Reference } & \multicolumn{1}{c|}{ Remarks } \\
\hline Antarctica & Lopez-Garcia et al. 2001 & $\begin{array}{l}\text { Sequences related to } \\
\text { labyrinthulids found at } 2000 \\
\text { m }\end{array}$ \\
\hline $\begin{array}{l}\text { English Channel off } \\
\text { Roscoff }\end{array}$ & Vaulot et al. (2002) & $\begin{array}{l}\text { 2 out of 108 clones } \\
\text { (including 26 stramenopile } \\
\text { clones) belonging to } \\
\text { thraustochytrids }\end{array}$ \\
\hline Anoxic Cariaco Basin & Stoeck et al. (2003) & $\begin{array}{l}\text { 1 clone closest to } \\
\text { Oblongichytrium } \\
\text { multirudimentale } \text { (S. } \\
\text { Goldst.) R. Yokoy. } \text { et D. }\end{array}$ \\
$\begin{array}{l}\text { Honda (as } \\
\text { Thraustochytrium } \\
\text { multirudimentale S. } \\
\text { Goldst.) at 270 and 340 m } \\
\text { depth }\end{array}$ \\
\hline $\begin{array}{l}\text { Berkeley Aquatic Park } \\
\text { (anoxic environment) }\end{array}$ & Dawson and Pace (2002) & $\begin{array}{l}\text { 1 clone close to } \\
\text { Aplanochytrium minuta } \\
\text { (S.W. Watson } \text { et } \text { Raper) } \\
\text { C.A. Leander } \text { et } \text { D. Porter. }\end{array}$ \\
\hline $\begin{array}{l}\text { Western edge of GNB } \\
\text { (Greenland, Norwegian and } \\
\text { Barents Sea) transect }\end{array}$ & Lovejoy et al. (2006) & $\begin{array}{l}\text { 1 clone close to } \\
\text { thraustochytrids }\end{array}$ \\
\hline $\begin{array}{l}\text { Long Island, New York, } \\
\text { USA }\end{array}$ & $\begin{array}{l}\text { Collado-Mercado et al. } \\
\text { (2010) }\end{array}$ & $\begin{array}{l}\text { 68 amplicons belonging to } \\
\text { Labyrinthulomycetes }\end{array}$ \\
\hline
\end{tabular}


Table 3 Abundances of Labyrinthulomycetes in different habitats in comparison with bacteria.

\begin{tabular}{|l|l|l|l|}
\hline Labyrinthulomycetes & \multicolumn{1}{|c|}{ Bacteria } & \multicolumn{1}{|c|}{ Location } & \multicolumn{1}{|c|}{ Reference } \\
\hline $56 \times 10^{3} 1^{-1}$ seawater & $\begin{array}{l}0.65 \times 10^{9} 1^{-1} \\
\text { seawater }\end{array}$ & Coastal Japan waters & $\begin{array}{l}\text { Naganuma et al., } \\
1998\end{array}$ \\
\hline $50 \times 10^{3} 1^{-1}$ seawater & $2.5 \times 10^{9} 1^{-1}$ seawater & Coastal Japan waters & Kimura et al., 1999 \\
\hline $21.4 \times 10^{3} 1^{-1}$ seawater & $\begin{array}{l}65.6 \times 10^{9} 1^{-1} \\
\text { seawater }\end{array}$ & Coastal Japan waters & Kimura et al., 2001 \\
\hline $130 \times 10^{3} 1^{-1}$ seawater & $\begin{array}{l}0.9 \times 10^{9} 1^{-1} \\
\text { seawater }\end{array}$ & Arabian Sea & $\begin{array}{l}\text { Raghukumar et al., } \\
2001\end{array}$ \\
\hline sediment & $3.56 \times 10^{9} \mathrm{~g}^{-1}$ & Fish-farm impacted \\
seagrass beds & $\begin{array}{l}\text { Bongiorni et al., } \\
2005\end{array}$ \\
\hline $230 \times 10^{3} 1^{-1}$ seawater & $\begin{array}{l}0.6 \times 10^{9} 1^{-1} \\
\text { seawater }\end{array}$ & $\begin{array}{l}\text { Greenland and } \\
\text { Norwegian Seas }\end{array}$ & $\begin{array}{l}\text { Naganuma et al., } \\
2006\end{array}$ \\
\hline $675 \times 10^{3} 1^{-1}$ seawater & $\begin{array}{l}3.5 \times 10^{9} 1^{-1} \\
\text { seawater }\end{array}$ & $\begin{array}{l}\text { Equatorial Indian } \\
\text { Ocean }\end{array}$ & $\begin{array}{l}\text { Damare and } \\
\text { Raghukumar, 2008 }\end{array}$ \\
\hline
\end{tabular}




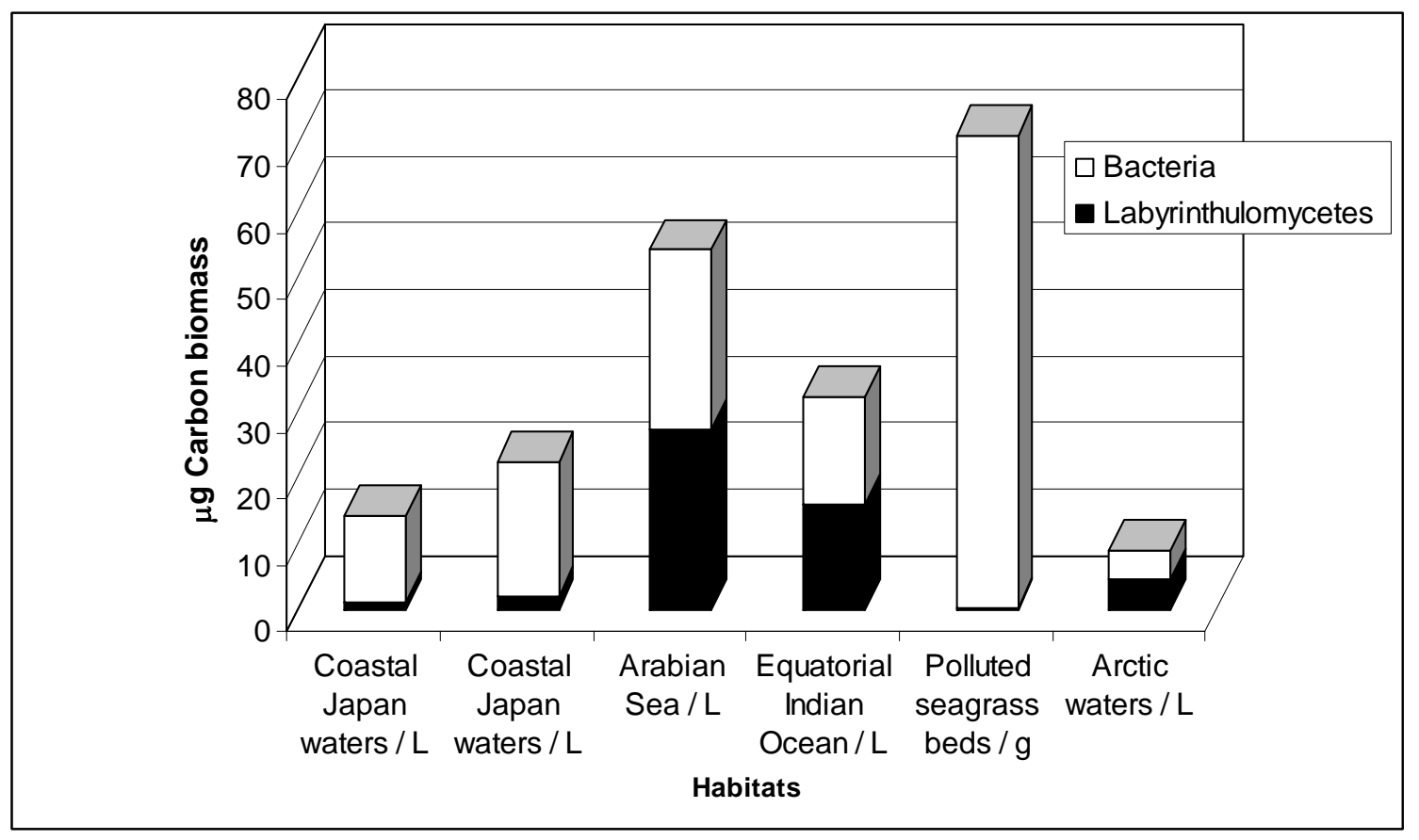

Fig. 1. S. Raghukumar and V. Damare. 

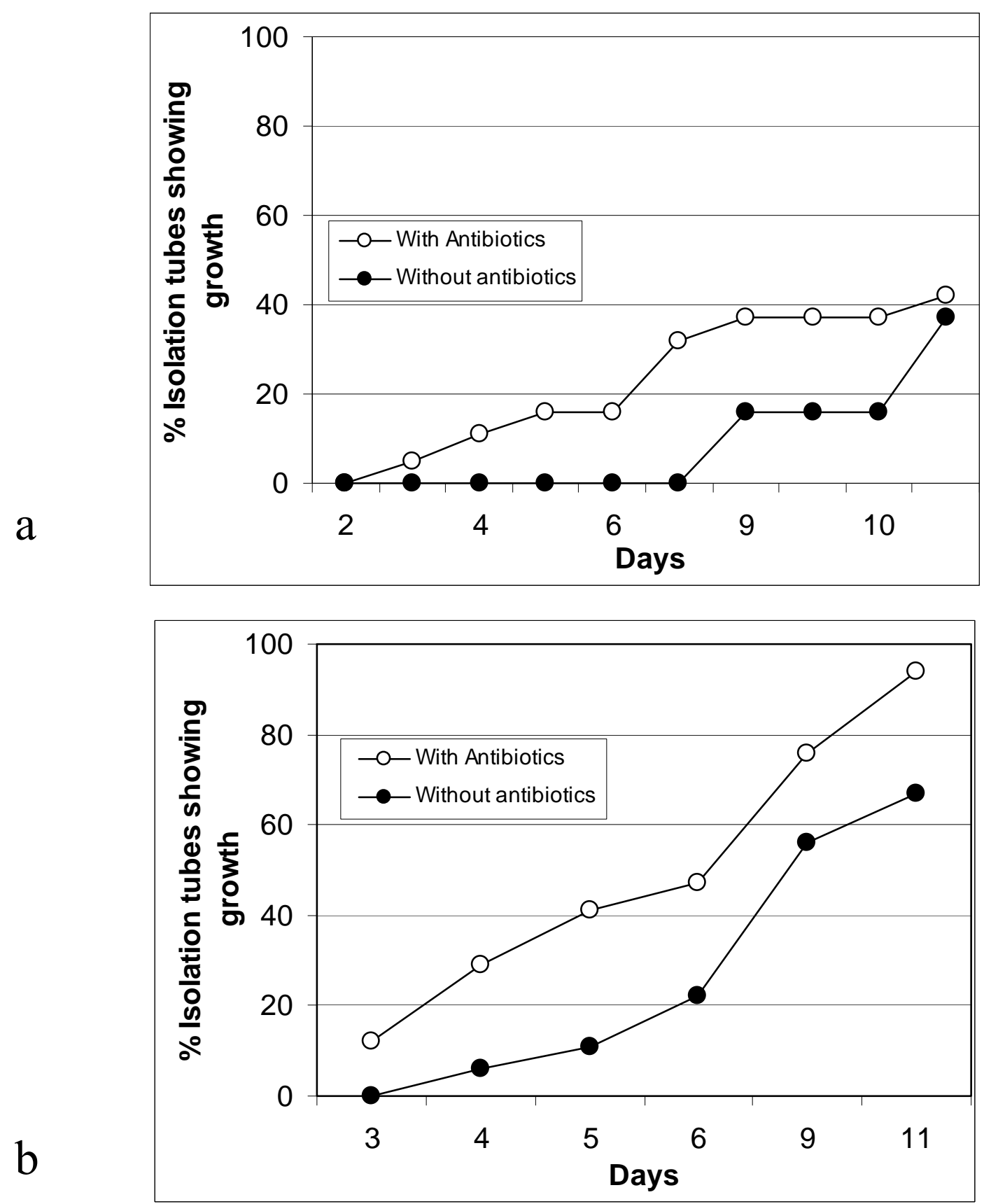

Fig. 2. S. Raghukumar and V. Damare 

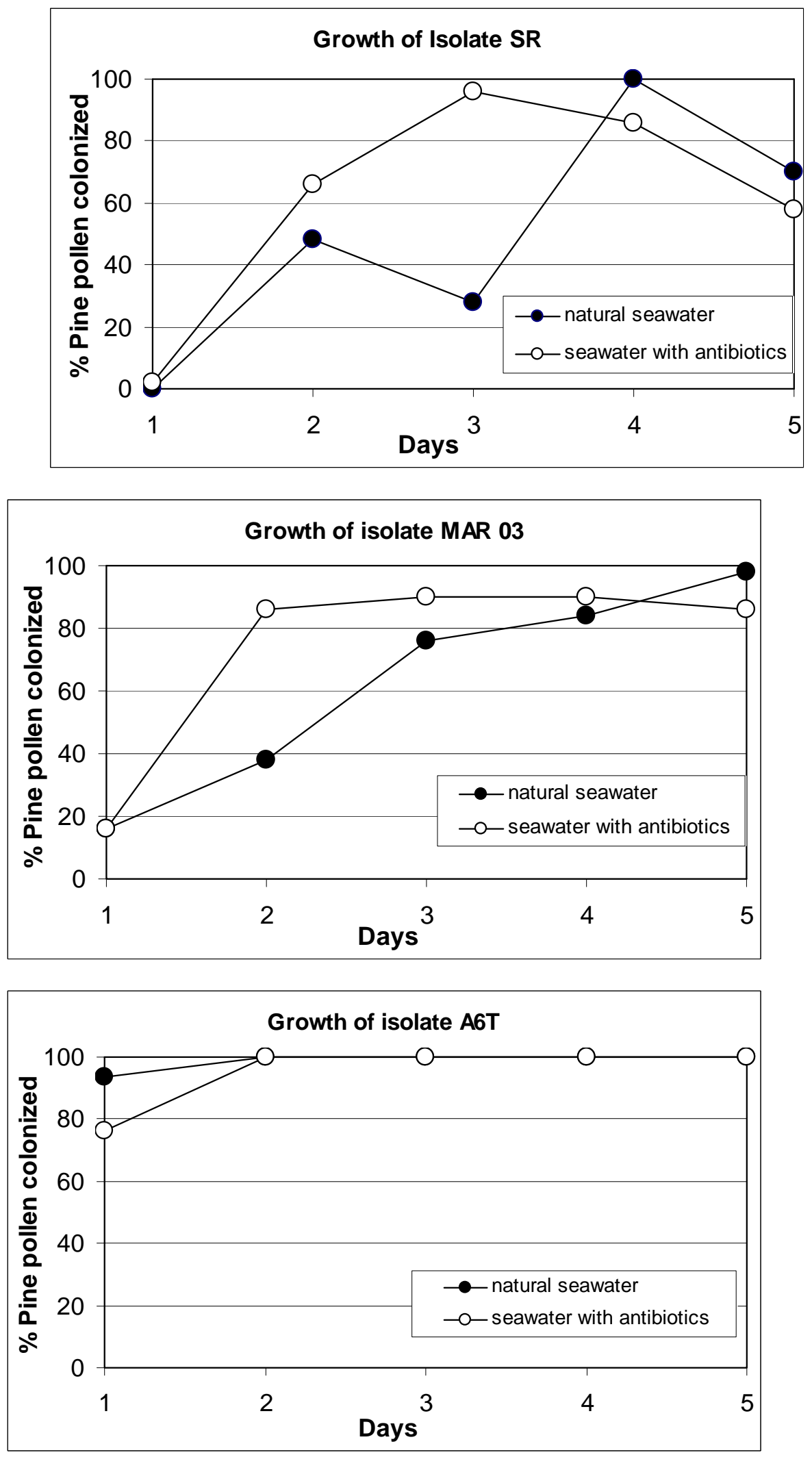

Fig. 3. S. Raghukumar and V. Damare 